\title{
Pengembangan Proses Produksi Opak Singkong di Kabupaten Pandeglang Melalui Implementasi Mesin Pencetak
}

\author{
Akbar Gunawan ${ }^{1}$, Nurul Ummi ${ }^{2}$, Putro Ferro Ferdinant ${ }^{3}$, Ade Irman ${ }^{4}$ \\ 1,2,3,4 Universitas Sultan Ageng Tirtayasa
}

\begin{tabular}{|c|c|}
\hline ARTICLE INFO & ABSTRACT \\
\hline \multirow{9}{*}{$\begin{array}{l}\text { Article History: } \\
\text { Received 14.09.2018 } \\
\text { Received in revised } \\
\text { form } 15.11 .2018 \\
\text { Accepted } 03.12 .2018 \\
\text { Available online } \\
\text { 21.12.2018 }\end{array}$} & $\begin{array}{l}\text { Pasirawi Village Banjar District Pandeglang Regency is one of the poorest } \\
\text { villages in Pandeglang District, where in this village there is productive land }\end{array}$ \\
\hline & $\begin{array}{l}\text { of cassava plantation area of approximately } 50 \text { hectares. This village is one of } \\
\text { the producers of Cassava Prawns one of them is the largest cassava opak in }\end{array}$ \\
\hline & Banten area. the production process of cassava opak cassava is still very \\
\hline & conventional so that in the process of processing there are some obstacles, \\
\hline & among others: production and technology constraints and still simple. \\
\hline & $\begin{array}{l}\text { Realizing the processed industry of Cassava in Pandeglang Regency qualified } \\
\text { and competitive through Implementation of Cassava Printing Machine }\end{array}$ \\
\hline & $\begin{array}{l}\text { Technology. Which is manifested in the activities Designing and } \\
\text { development of production machine Opak Cassava Chips Maker with Engine }\end{array}$ \\
\hline & $\begin{array}{l}\text { Speed } 100 \text { pcs / minute and other processed cassava printing machine which } \\
\text { result more efficient. }\end{array}$ \\
\hline & $\begin{array}{l}\text { Keywords: Cassava, Production Process, Technology, Cassava Opak, } \\
\text { Efficient. }\end{array}$ \\
\hline
\end{tabular}

DOI: $10.30653 / 002.201832 .67$

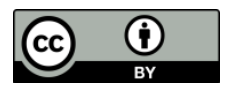

This is an open access article distributed under the terms of the Creative Commons Attribution 4.0 International License, which permits unrestricted use, distribution, and reproduction in any medium, provided the original work is properly cited. ( 2018 Akbar Gunawan, Nurul Ummi, Putro Ferro Ferdinant, Ade Irman.

\section{PENDAHULUAN}

Singkong merupakan tanaman yang berasal dari benua Amerika yang masuk ke wilayah Indonesia pada tahun 1852 (Putriana \& Aminah, 2013: 29). Dalam industri makanan, pengolahan singkong, dapat digolongkan menjadi tiga yaitu hasil fermentasi singkong (tape/peuyem), singkong yang dikeringkan (gaplek) dan tepung singkong atau tepung tapioka yang selanjutnya dipergunakan untuk berbagai macam industri seperti makanan, makanan ternak, kertas, kayu lapis, dan lainnya (Fitri, 2013). Hasil olahan ubi kayu (Manihot Esculenta) berupa tapioka dan gaplek dalam bentuk irisan (chips), pellet, atau lainnya, telah lama menjadi komoditi ekspor yang sangat penting dalam menyumbang pendapatan devisa, karenanya merupakan aset yang sangat berharga dan

${ }^{1}$ Corresponding author: Program Studi Teknik Industri, FT Universitas Sultan Ageng Tirtayasa Banten; Jl. Jend Sudirman Km 03, Cilegon, Banten; Email: a68ar@untirta.ac.id 
perlu dijaga kelestariannya sehingga dapat dimanfaatkan untuk pengembangan ekspor pada masa-masa selanjutnya.

Pengalaman petani menunjukkan bahwa penanaman ubi kayu sering tidak membuahkan hasil yang cukup baik untuk keluarga, karena keadaan tata niaga ubi kayu yang banyak dipengaruhi oleh fluktusi harga sehingga merugikan petani. Pada saat menjelang tanam, harga ubi kayu biasanya terlihat sangat menarik, sehingga banyak petani berusaha menanamnya. Sebaliknya, pada saat panen harga ubi kayu kemudian jatuh, sehingga banyak merugikan petani (berdasarkan data yang ada kapasitas pabrik dan potensi ekspor masih lebih besar dari jumlah produksi), untuk diketahui harga ubi kayu (singkong) basah pada saat panen dijual dengan harga Rp. 1.500/kg . Kondisi ini telah mendorong banyak petani untuk mengalihkan perhatian dan berusaha menanam komoditi lain. Di sisi lain, apabila hal ini terus dibiarkan, akan bisa berakibat turunnya produksi yang dapat menekan pasokan ubi kayu baik untuk keperluan ekspor ataupun konsumsi ubi kayu dalam negeri. Lemahnya posisi petani ubi kayu dalam menghadapi pengaruh fluktuasi harga, terutama disebabkan karena ubi kayu memiliki daya simpan yang rendah,dan produktifitasnya juga rendah akibat modal usaha yang sangat terbatas, disamping kebutuhan keluarga yang sudah sangat mendesak. Pendapatan petani ubi kayu akan makin rendah lagi karena pada saat dijual ke pabrik mendapatkan rendahnya mutu ubi kayunya. Berdasarkan kondisi yang ada, maka salah satu alternatif untuk mengantisipasi masalah tersebut di atas, adalah dengan mengolah singkong menjadi makanan olahan lainnya seperti: Kerpik Singkong, Opak Singkong, Mie Singkong, Tepung Mocaf, Tepung Tapioka, dan lain lain.

Desa Pasirawi merupakan salah satu desa penghasil keripik Opak Singkong. Keripik Opak Singkong merupakan salah satu makanan tradisional yang berbahan baku singkong sudah dikonsumsi sejak dulu. Opak banyak di produksi di desa Pasirawi, kecamatan Banjar, kabupaten Pandeglang Propinsi Banten. Luas lahan area perkebunan Singkong di desa Pasirawi Kecamatan Banjar Kabupaten Pandeglang sebesar 44 s/d 50 Hektar. Dimana masing-masing Kepala keluarga memiliki 0,5 s/d 1 Hektar lahan yang dipergunakan sebagai perkebunan singkong. Terdapat sentra industry Aneka Olahan Singkong yang dikelola oleh Kelompok Wanita Tani yaitu Kelompok Wanita Tani (KWT) Asih Bersama Desa Pasirawi.

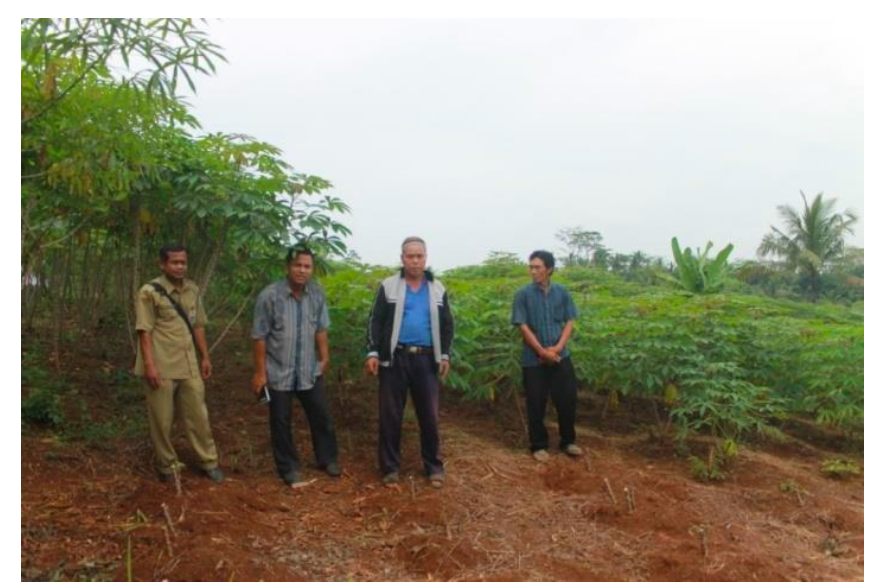

Gambar 1. Perkebunan Singkong di Desa Pasirawi

Keripik Opak Singkong selama ini menjadi sumber mata pencaharian bagi para masyarakat desa Pasirawi. Usaha ini tergolong jenis industri rumahan karena pengerjaannya secara individual di rumah masing-masing pengrajin. Penanaman dan 
pemanenan Singkong biasanya dilakukan oleh para pria, kemudian proses pengupasan singkong hingga menjadi Keripik Opak Singkong dilakukan oleh para wanita di rumah. Proses pembuatan Keripik Opak Singkong dilakukan dengan peralatan yang sangat sederhana, yaitu menggunakan pisau, panci kukusan, alu, jubleng, dulang, tungku kayu bakar, penggilingan dan cetakan plastik. Keripik Opak Singkong dari hasil produksi pengrajin masyarakat Pasirawi biasanya langsung dijual ke pengumpul yang datang setiap hari tertentu ke kampung tersebut untuk kemudian di jual ke pasar dan pedagang besar di kota.

Sentra industri Keripik Opak Singkong Kelompok Wanita Tani (KWT) Asih Bersama yang berlokasi di Desa Pasirawi Kecamatan Banjar Kabupaten Pandeglang. Kelompokusaha ini mempunyai 38 anggota kelompok dengan 100 Unit Usaha Keripik Opak Singkong rumah Tangga. Fasilitas Produksi: Saung/bangunan untuk proses produksiSaung digunakan untuk aktivitas produksi dilakukan di rumah-rumah penduduk. Rencananya Kelompok Wanita Tani (KWT) Asih Bersama akan menyediakan satu rumah/ area untuk proses produksi Keripik Opak Singkong bersama.Lahan penjemuran Luas lahan penjemuran disesuaikan dengan skala usaha. Tempat penyimpanan Keripik Opak Singkong yang sudah jadi

Peralatan yang dibutuhkan dalam usaha Keripik Opak Singkong relatif sederhana, yaitu: pisau, bak/ember untuk mencuci singkong, panci/dandang untuk merebus singkong, tungku kayu bakar, alu, jubleng (dulang) untuk menumbuk singkong yang sudah masak,penggilingan dan alas plastik, cetakan plastik untuk mencetak Keripik Opak Singkong, irig dari bambu untuk alas menjemur Opak. Bahan baku utama yang dibutuhkan untuk usaha Keripik Opak Singkong adalah Singkong jenis manggu dan Singkong Mentega selain itu dibutuhkan juga bahan baku lainnya untuk opak yang memiliki rasa manis pedas yaitu: garam, cabe rawit, bawang putih, gula putih.

Tenaga kerja pada usaha Keripik Opak Singkong umumnya berasal dari anggota keluarga dan masyarakat di sekitar lokasi usaha. Tenaga kerja keluarga biasanya dipraktekkan di tingkat pengrajin, yaitu menanam dan memanen Singkong oleh anggota keluarga laki-laki dan dibantu anggota keluarga perempuan sebagai pengolah singkong menjadi Keripik Opak Singkong. Dengan jumlah tenaga kerja sebanyak kurang lebih 100 orang yang tersebar di semua rumah penduduk.

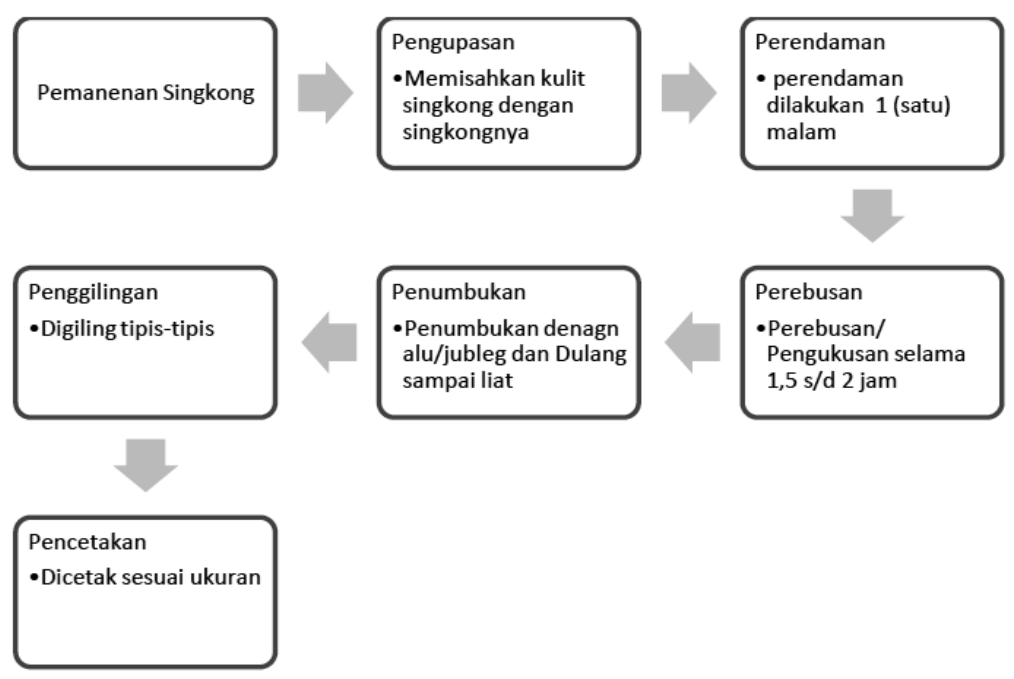

Gambar 2. Skema Proses Produksi Pengolahan Keripik Opak Singkong Setengah Jadi 
Teknologi usaha Keripik Opak Singkong di tingkat pengrajin, yaitu dengan menggunakan peralatan yang konvensional dan sederhana. Penggunaan alat sederhana berpengaruh pada kapasitas produksi dan mutu yang relatif rendah. Proses produksi Keripik Opak Singkong seperti dijelaskan pada skema di Gambar 2.

Pemanenan singkong dilakukan oleh para kelompok tani, adapun jenis singkong yang di budi dayakan untuk Keripik Opak Singkong adalah jenis singkong manggu dengan panjang s/d $70 \mathrm{~cm}$ dan jenis singkong mentega mas dengan panjang kurang lebih $30 \mathrm{~cm}$ dan umur panen kurang lebih 5 bulan.

Kendala yang dilakukan Industri Keripik Opak Singkong. Teknologi yang digunakan untuk mencetak Keripik Opak Singkong masih sederhana hanya menggunakan alat seadanya. Diantaranya: mangkok, plastik dan minyak goreng sebagai pelumas. Berdasarkan uraian profil dan kendala di atas, beberapa kebutuhan yang dialami oleh industri Keripik Opak singkong khususnya KWT di Kabupaten Pandeglang adalah sebagai berikut: 1) Dibutuhkan suatu alat yang dapat dipergunakan untuk mencetak Keripik Opak Singkong, sehingga menghasilkan Opak singkong yang sama ketebalannya; 2) Dibutuhkan suatu teknik dan alat tertentu untuk dapat mencetak keripik opak singkong dengan kapasitas yang banyak dan dalam waktu yang cepat dengan ukuran yang sama.

\section{Masalah}

Aneka Olahan Singkong merupakan salah satu bahan makanan yang digalakkan oleh Pemda Kabupaten Pandelang sebagai diversifikasi pangan selain dari pada padi. Potensi Bahan baku Singkong di Kabupaten Pandeglang tersedia dalam jumlah yang banyak. Disamping itu tersedia Kelompok-kelompok Tani dan Kelompok Wanita Tani yang mengembangkan industry rumah tangga yang diharapkan akan dapat menjadi pendorong bagi pengembangan Aneka Olahan Singkong di Kabupaten Pandeglang. Potensi bahan baku Singkong di Kabupaten Pandeglang disajikan pada Tabel 1.

Tabel 1. Potensi Bahan Singkong di Kabupaten Pandeglang

\begin{tabular}{ccccc}
\hline \multirow{2}{*}{$\begin{array}{c}\text { Jenis Tanaman } \\
\text { Pangan }\end{array}$} & \multicolumn{2}{c}{ Luas Lahan Produksi (Ha) } & \multicolumn{2}{c}{ Jumlah Produksi (Ton) } \\
\cline { 2 - 5 } & 2013 & 2014 & 2013 & 2014 \\
\hline Ubi Kayu & $2.664,0$ & $2.875,0$ & $61.005,6$ & $64.098,4$ \\
\hline
\end{tabular}

Hal lain yang menjadi pendukung sebagai potensi aneka olahan singkong di Kabupaten Pandeglang adalah sudah tersedianya pasar-pasar yang menampung hasil aneka hasil olahan Singkong seperti dipusat pasar Kota Pandeglang, Serang, Rangkasbitung dll. Dengan dijadikannya Aneka Olahan Singkong sebagai produk diversifikasi pangan Kabupaten Pandeglang diharapkan akan terus berkembang dan sentra pasar penjualan semakin maju sehingga akan menjadikan tempat wisata baru yang dapat menarik pengunjung untuk mengunjungi Kabupaten Pandeglang dengan kekhasan aneka ragam olahan Singkong. Sentra produksi Aneka Olahan Singkong tersebar dibeberapa daerah Kecamatan di Kabupaten Pandeglang.

Salah satu diversifikasi produk Aneka Olahan Singkong adalah Keripik Opak Singkong. Untuk itu pemerintah Kabupaten Pandeglang sangat berkepentingan terhadap pengembangan Industri Keripik Opak Singkong dan olahan singkong lainnya yang berpotensi untuk pasar lokal dan nasional. Salah satu strategi guna mewujudkan tujuan 
pemerintah tersebut, pihak pemerintah daerah kabupaten Pandeglang berkepentingan bekerjasama dengan perguruan tinggi dan industri pengolahan Aneka Olahan Singkong untuk dalam hal:

1) Peningkatan Kelembagaan

2) Peningkatan SDM

3) Penguatan Jejaring Bahan Baku dan Pemasaran produk

4) Penguatan teknologi Inovasi Produk, sarana dan prasarana

5) Pelatihan dan pendampingan kepada mitra industri dalam pengolahan produksi pengolahan aneka Singkong

Solusi bagi permasalahan yang dihadapi Mitra Industri Aneka Olahan Singkong di Pandeglang dan membantu pemerintah daerah Pandeglang dalam hal peningkatan Industri Aneka Olahan Singkong di Kabupaten Pandeglang dengan cara memberikan sumbangsih pemikiran dan tenaga guna: 1) Menciptakan suatu Alat Teknologi (Mesin) yang dapat memproduksi Aneka olahan Singkong; 2 Memberikan pelatihan dan pendampingan kapada mitra industri dalam proses pencetakan.

\section{METODE PELAKSANAAN}

Berdasarkan analisis situasi yang telah disampaikan pada bab satu, solusi yang ditawarkan melalui program pengabdian adalah Pengembangan Proses Produksi aneka olahan singkong pada Keripik Opak Singkong melalui Teknologi mesin cetak di Kabupaten Pandeglang. Kegiatan program pengabdian diawali dengan kegiatan survei kondisi lapangan bagaimana proses pembuatan keripik Opak Singkong yang selama ini dilakukan oleh pengrajin kelompok wanita tani, Selanjutnya adalah sosialisasi rencana pelaksanaan pengabdian ke mitra industri dengan sasaran meliputi dua kampung yaitu kampung Cibogo dan Kampung Ciheas Desa Pasirawi, adapun sosialisasi yang akan dibangun adalah penerapan teknologi mesin pencetak opak singkong.

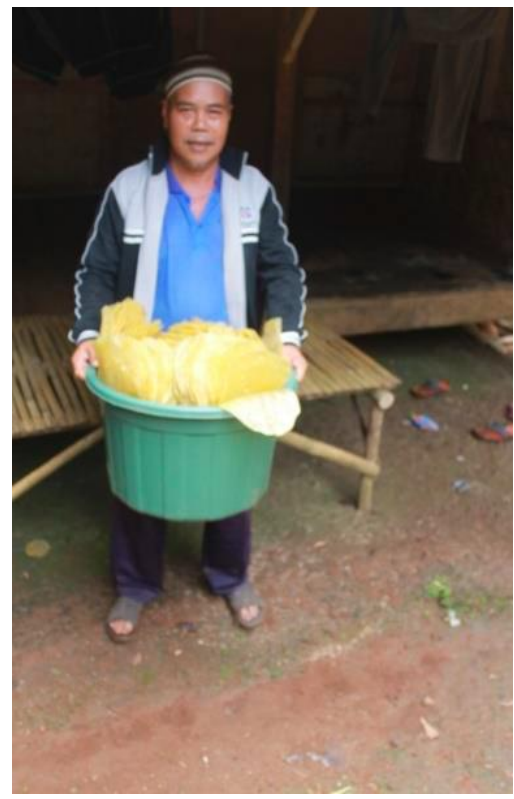

Gambar 3. Keripik Opak Singkong yang dihasilkan 
Mengingat kondisi pengrajin yang biasanya mereka membuat produk secara konvensional dan menjual produk Keripik Opak Singkong dalam bentuk setengah jadi atau (curah) ke pengumpul, maka pada tahun pertama dilakukan pengembangan proses pembuatan Keripik Opak Singkong dengan cara pengenalan teknologi tepat guna pada proses pengolahan Opak Singkong dengan mempergunakan mesin cetak untuk memperbaiki kondisi pembuatan Keripik Opak Singkong yang masih konvensional. Selanjutnya adalah mengemas produk yang setengah jadi untuk kripik opak singkong yang belum di goring dengan menggunakan kemasan ukuran $0,5 \mathrm{~kg} s / \mathrm{d} 1 \mathrm{~kg}$. Berikut ini adalah gambaran kondisi Keripik Opak Singkong yang dihasilkan oleh pengrajin Opak Singkong di kecamatan Banjar, Pandeglang saat ini. Untuk itu diperlukan beberapa proses perbaikan pembuatan Keripik Opak Singkong agar lebih berkualitas, pada program pengabdian tahun pertama dilakukan pengadaan mesin-mesin produksi meliputi mesin giling dan mesin cetak keripik opak singkong.

\section{HASIL DAN PEMBAHASAN}

Program pembuatan mesin ini akan dipadukan dengan berbagai pelatihan bagi pengrajin yang tergabung dalam kelompok Wanita Tani (KWT) Asih Bersama berupa proses pengolahan aneka singkong, proses penanganan banan baku, proses produksi, pengemasan dan pemasaran produk. Pemberian pelatihan juga diberikan kepada para Staff dan anggota KWT Asih Bersama berupa implementasi prinsip-prinsip kemandirian penggunaan dan perawatan mesin, sehingga program pembangunan industri Keripik Opak Singkong dapat tercapai dengan baik.

Disamping itu untuk penguatan lembaga KWT Asih Bersama dan perlu didukung dengan program pelatihan dan pendampingan baik itu pelatihan dan pendampingan pengoperasian alat dan mesin maupun perwatan mesin produksi. Selain itu untuk melindung hasil temuan dari penelitian ini berupa alat pembuatan Keripik Opak Singkong yang terbarukan, perlu kiranya didaftarkan patennya. Hasil-hasil yang telah dicapai dalam kegiatan Proses Produksi opak Singkong di Kabupaten Pandeglang pada tahun pertama adalah sebagai berikut:

\section{Program I: Sosialisasi pelaksanaan HI-Link ke mitra Industri KWT Asih Bersama di Desa Pasirawi Kecamatan Banjar Kabupaten Pandeglang}

Program ini dilakukan dengan kegiatan kunjungan ke pengrajin aneka olahan Singkong di kecamatan Banjar Kabupaten Pandeglang, mengenai program HI-Link. Adupun hasil dari program yang dijalankan, yaitu:

1) Masyarakat antusias terhadap adanya program Hi-Link di desa Pasirawi, mereka berharap dengan adanya kegiatan Hi-Link ini menjadikan adanya nilai tambah dari produk aneka olahan singkong kususnya Opak Singkong, terutama harga jual setelah adanya modifikasi produk Opak Singkong.

2) KWT Asih Bersama berlokasi di desa Pasirawi Kecamatan Banjar Kabupaten Pandeglang memiliki 38 anggota kelompok pengolahan Singkong yang salah satunya berupa Keripik Opak Singkong.

3) Terdapat dua macam Jenis keripik Opak singkong yang dihasilkan KWT Asih Bersama yaitu keripik Opak Singkong Original \& Keripik Opak Singkong asin Pedas. Untuk Keripik Opak Singkong Original berdiameter besar sedangkan Opak Singkong yang asin pedas berdiameter kecil. Rata-rata para pengarjin Opak membuat Keripik Opak 
Singkong $10 \mathrm{Kg} /$ hari atau setara dengan 400 pcs Keripik Opak Yang besar atau 1000 pcs Opak yang ukuran kecil.

4) Saat ini kedua jenis Opak tersebut dijual secara curah berbentuk keripik opak yang belum matang atau siap goreng. Pemasarannya dijual kepada pengepul yang akan datang tiap dua hari sekali.

5) Permintaan kedua jenis Opak (Original dan Asin Pedas) sangat Tinggi.

6) Rumah Produksi yang disediakan warga untuk kegiatan Hi-Link ini berukuran: $10 \mathrm{~m}$ $\mathrm{x} 5 \mathrm{~m}$.

7) Harga jual keripik Opak yang besar (yang belum matang) Rp. 80 untuk yang kecil dan Rp. 160 untuk yang besar. Rata-rata pendapatan/ pengrajin/ hari untuk Opak Besar adalah 400 pcs $\times$ Rp. $160=$ Rp. 64.000. dan untuk Opak ukuran kecil adalah 1000 pcs $x$ Rp. $80=$ Rp. $80.000,00$.

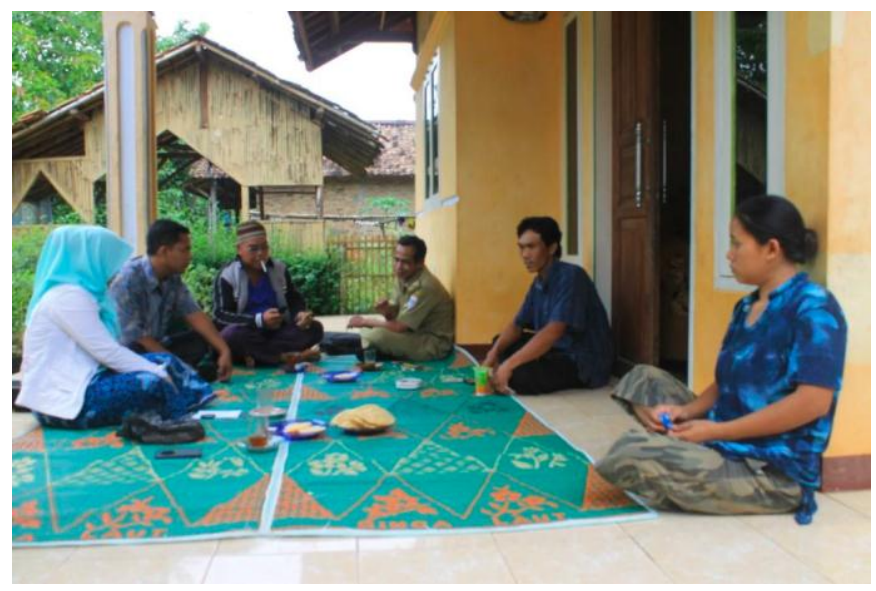

Gambar 4. Sosialisasi Rencana Kegiatan Hi-Link di Desa Pasirawi Kecamatan Banjar Kabupaten Pandeglang

\section{Program II: Penyeragaman Bahan Baku Aneka Olahan Singkong}

Kegiatan dalam program ini meliputi Pembuatan SOP penerimaan Bahan baku singkong. Uji coba jenis singkong yang digunakan untuk bahan baku pembuatan opak yang terdiri dari singkong manggu, singkong mentega, singkong putih, songkong mukibat dan singkong gajah. Diperoleh hasil bahwa singkong manggu merupakan bahan baku terbaik dibandingkan dua jenis singkong lainnya, hal ini dinuktikan dengan rasa opak yang dibuat dari singkong manggu memiliki rasa sedikit manis, sedangkan jenis singkong lain cenderung menghasilkan opak yang berasa tawar bahkan pahit.

\section{Program III: Pengadaan Mesin Giling}

Mesin giling digunakan untuk menggiling Singkong yang sudah di rebus, selanjutnya masuk kedalam mesin rolling untuk dipipihkan dan selanjutnya setelah dipipihkan dengan ketebalan yang bisa diatur, di cetak menggunakan roller cutter sesuai ukuran Keripik Opak Singkong yang semuanya berada dalam satu mesin dan dilengkapi Conveyor dengan belt standar food grade, sehingga memudahkan pengerjaan. 

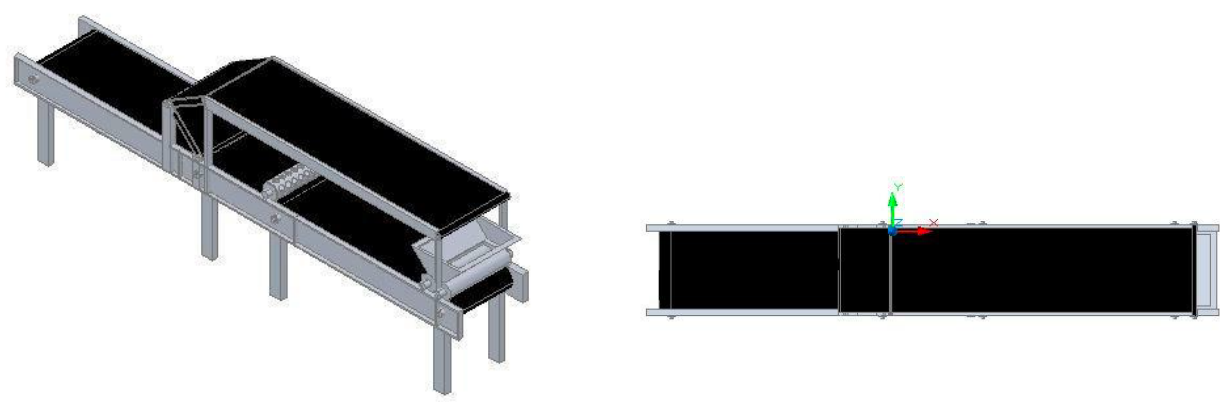

Gambar 4. Mesin Giling Opak Singkong Isometric

\section{Program IV: Penerapan Teknologi Pembuatan Mesin Press dan Cetak Opak Singkong}

Kegiatan dalam program ini meliputi pengadaan dan pelatihan pengoperasian mesin rolling dan cetak. Pembuatan Mesin Pipih (rolling) dan Pencetak Opak Singkong. Mesin rolling dan pencetak mejadi satu kesatuan mesin, proses pemipihan dilakukan dengan adanya rolling stainless yang merubah adonan singkong menjadi lapisan singkong dengan ketebalan tertentu. Adonan singkong yang telah pipih dengan ketebalan tertentu akan dicetak oleh mesin pencetak berupa roller cutter. Bentuk cetakan dapat diganti sesuai dengan keinginginan KWT dalam membetuk bentuk dan ukuran opak. Mesin ini mengunakan motor listrik berdaya 1300 watt.

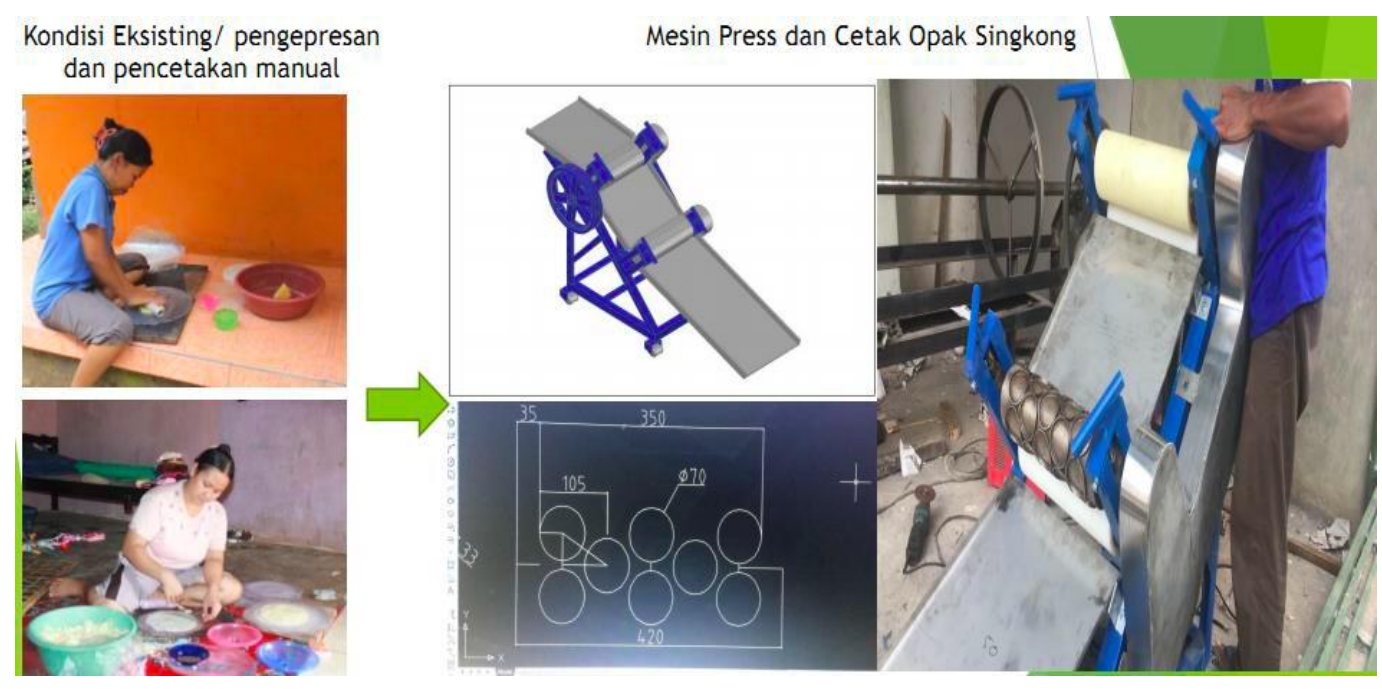

Gambar 5. Kondisi Sebelum dan Sesudah ada Mesin Pemipih \& Pencetak Opak Singkong

Pelatihan penggunaan mesin cetak dilakukan untuk memberikan keahlian kepada anggota KWT Asih Bersama di dalam mengoperasikan mesin cetak dengan baik dan benar. Mesin Cetak ini mampu mencetak 37 singkong dalam satu putaran mesin dalam waktu 3-5 detik saja. 

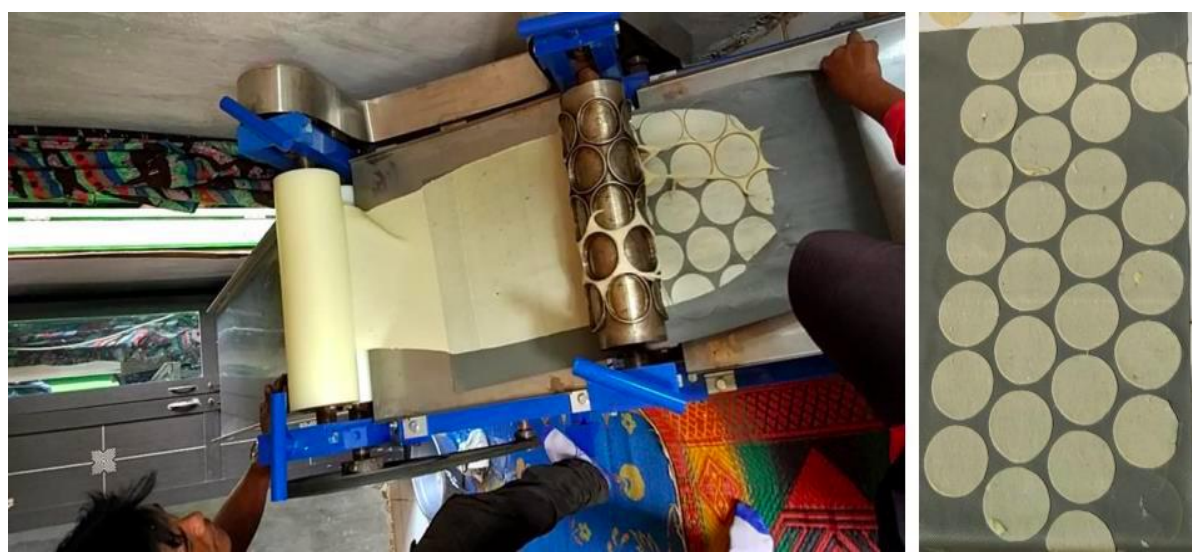

Gambar 6. Pelatihan Penggunaan Mesin Pemipih E Pencetak Opak Singkong

\section{SIMPULAN}

Kegiatan Pengabdian Tahun ke-1 yang telah dilaksanakan di KWT Asih Bersama Kecamatan Banjar Kabupaten Pandeglang memberikan dampak yang positif terhadap masyarakat khususnya masyarakat produsen aneka olahan singkong yang turut berpartisipasi dalam program-program pengabdian. Program pengabdian pada tahun ini memberikan konstrubusi positif terutama dalam hal: 1) Meningkatkan kemampuan Dosen dan mahasiswa dalam penerapan ilmu pengetahuan dan teknologi sesuai dengan bidang ilmu dan keahliannya masing-masing; 2) Meningkatkan kemampuan masyarakat khusunya masyarakat produsen KWT Asih Bersama dalam proses produksi Opak Singkong menggunakan teknologi Mesin press \& mesin Cetak yang efektif dan efisien dalam proses kerjanya; 3) Dihasilkannya pengolahan opak singkong yang efektif dan efisien dengan menerapkan teknologi mesin press dan mesin cetak Tim pengabdian; dan 4) Dihasilkan variasi produk Opak KWT Asih Bersama baik dari segi rasa maupun bentuk.

\section{UCAPAN TERIMA KASIH}

Untuk terlaksananya pengabdian tersebut banyak kerjasama dengan mitra dan tim eksternal lainnya. Sebagai bukti terima kasih yang sebanyak-banyaknya kami haturkan diantaranya: Kemenristek Dikti yang memberikan hibah pengabdian dalam program HiLink, Pemerintahan Kota Pandeglang, Anggota Dewan Kota Pandeglang, Dinas Ketahanan Pangan kota pandeglang, tim KWT Asih Bersama dan mahasiswa yang membantu mengsukseskan program pengabdian ini.

\section{REFERENSI}

Adelaar, T. (2000). Electronic commerce and the implications for market structure. Journal of Computer-Mediated Communication, 5(3), JCMC531.

Arnott, D. C., \& Bridgewater, S. (2002). Internet, interaction and implications for marketing. Marketing Intelligence dan Planning, 20(2), 86-95. 
Brown J. G. (1994). Agroindustrial Invesment and Operations. Washington: The Word Bank.

Bennet, R. (1997). Export marketing and the internet: Experience of web site use an perceptions of export barriers among UK. Businesses. Industrial Marketing Review, 14(5), 324-344.

Chaffey, D., Mayer R., Johnston, K., \& Elliss-Chadwick, F. (2000). Internet marketing: Strategy, implementation, and practice. England: Prentice Hall.

Fitri, R. (2013). Diversifikasi olahan singkong dan pisang. Yogyakarta: UNY Press.

Putriana, I., \& Aminah, S. (2013). Mutu fisik, kadar serat dan sifat organoleptik nata de cassava berdasarkan lama fermentasi. Jurnal Pangan dan Gizi, 4(1), 29-38. 